\title{
SISTEM PENDUKUNG KEPUTUSAN PENENTUAN PENERIMAAN RASKIN DI MENGGUNAKAN METODE TOPSIS
}

\author{
Masitah Handayani \\ Sekolah Tinggi Manajemen Informatika Komputer Royal Kisaran, Asahan \\ masitah handayani@gmail.com
}

\begin{abstract}
Abstrak - Selama ini di Desa Mekar Sari dalam pengambilan keputusan untuk penerimaan Raskin masih menggunakan cara manual. Kendalanya adalah kesulitan dalam penyimpanan atau pencarian arsip yang telah tersimpan, serta masalah pembuatan laporan yang terlambat juga menghambat penyampaian informasi.Banyak keluarga yang seharusnya tidak mendapatkan Raskin tetapi menerima raskin juga, sebaliknya untuk keluarga miskin yang seharusnya mendapatkan Raskin tetapi tidak mendapatkannya.Berdasarkan latar belakang tersebut maka penelitian ini dilakukan dengan tujuan untuk mengembangkan sebuah aplikasi sistem pendukung keputusan yang memudahkan pihak terkait dalam memberikan keputusan dalam hal pemilihan keluarga miskin yang berhak menerima Raskin di Desa Mekar Sari Dusun 5. Metode yang digunakan dalam pengembangan sistem adalah metode TOPSIS,dimana metode topsis adalah salah satu metode pengambilan keputusan dimana alternative yang terpilih merupakan alternatif terbaik yang mempunyai jarak terdekat dari solusi ideal positif dan terjauh dari solusi ideal negatif.
\end{abstract}

Kata Kunci - Raskin , Sistem pendukung keputusan, TOPSIS.

Abstrack - During this time in the village of Mekar Sari in making decision to accept Raskin still use manual way. The obstacles are the difficulty in storing or retrieving archives that have been stored, and the problem of late reporting also hampers the delivery of information. Many families should not get Raskin but accept raskin as well, otherwise for poor families who should get Raskin but do not get it.Based on the background Then this research is conducted with the aim to develop an application of decision support system that facilitate the related party in giving decision in the case of election of poor family entitled to receive Raskin in Village Mekar Sari Dusun 5. The method used in system development is TOPSIS method, where method of topsis Is one of the decision-making methods in which the chosen alternative is the best alternative that has the closest distance from the ideal ideal solution and furthest from the ideal negative solution.

Keywords - Raskin, decision support system, TOPSIS

\section{PENDAHULUAN}

Berdasarkan Instruksi Presiden Nomor 1 Tahun 2008 tentang Kebijakan Perberasan, Perusahaan Umum (Perum) Badan Usaha Logistik (BULOG) yang diberikan penugasan oleh Pemerintah untuk melaksanakan kegiatan pengelolaan serta melakukan kegiatan persediaan, distribusi, dan kemudian juga untuk melakukan pengendalian terhadap harga beras yang ada melalui pengamanan stok beras, juga untuk pengamanan harga dasar beras dan penyalurannya termasuk Program Beras Untuk Keluarga Miskin 
(RASKIN), serta stabilisasi harga beras, dengan berdasarkan pertimbangan.

Raskin merupakan program pemerintah dengan tujuan, melalui komoditas beras, meningkatkan akses pangan keluarga miskin, memenuhi kebutuhan pangan pokok, dalam rangka menguatkan ketahanan pangan di rumah-rumah tangga dan mencegah penurunan konsumsi energi dan protein.Kegiatan ini dikenal sebagai program raskin (beras miskin). Raskin diberikan setiap periode triwulan (tiga bulan) kepada keluarga kurang mampu sebanyak 15 kg/bulan selama kurun waktu 12 bulan dengan harga netto Rp. 1600/kg. Penelitian yang dilakukan di Desa Mekar Sari dalam pengambilan keputusan penerimaan Raskin masih menggunakan cara manual dan pendataan masih dalam bentuk kertas, sehingga membutuhkan waktu yang lama untuk pengolahan dan kendala terbesar adalah kesulitan dalam penyimpanan atau pencarian arsip yang telah tersimpan jika akan dicocokkan dengan informasi atau pedoman yang baru diperoleh.

Penyaluran Raskin lewat tiap-tiap RT, Ketua RT yang menentukan berhak dan tidaknya keluarga untuk mendapatkan Raskin.Banyak keluarga yang seharusnya tidak mendapatkan Raskin tetapi menerima raskin juga, sebaliknya untuk keluarga miskin yang seharusnya mendapatkan Raskin tetapi tidak mendapatkannya dan proses penyeleksian ini berjalan sangat lambat.Pengambilan keputusan untuk menentukan kriteria penerima beras yang sudah terjadi biasanya tidak mengacu pada kriteria-kriteria keluarga miskin.Sistem Pendukung Keputusan (SPK) adalah bagian dari sistem Informasi berbasis komputer, termasuk sistem berbasis pengetahuan (manajemen pengetahuan) yang dipakai untuk mendukung pengambilan keputusan dalam suatu organisasi atau sebuah perusahaan.Selain itu sistem pendukung keputusan dipakai untuk mencari solusi berdasarkan kriteria-kriteria tertentu dan memberikan berbagai alternatif pilihan.

\section{A. Pengertian Sistem Pendukung Keputusan}

Sistem pendukung keputusan

(SPK)

biasanyadibangun untuk mendukung soluasi atas suatu masalahatau mengevaluasi suatu peluang.Sistem pendukungkeputusan yang seperti itu disebut aplikasi sistempendukung keputusan. Aplikasi ini menggunakanCBIS (Computer Based Information System) yang fleksibel, interaktif dan dapat diadaptasi yang dikembangkan untuk mendukung solusi atas masalahmanajemen spesifik yang tidak terstruktur, (Kursini, 2007).

Menurut Turban , Rainer, Potter (2005, h.321) SistemPendukung Keputusan (SPK) adalah suatu sistem informasi berbasis computer mengkombinasikan model dan data untuk menyediakan dukungan kepada pengambil keputusan dalam memecahkan masalah semi terstruktur atau masalah ketergantungan yang melibatkan user secara mendalam.Sistem Pendukung Keputusan merupakan sebuah sistem yang menyediakan kemam puan untuk penyelesaian masalah dan komunikasi untuk permasalahan yang bersifat semi terstruktur (Raymond McLeod, Jr. (1998)

Menurut Little (1970), Sistem Pendukung Keputusan adalah sebuah himpunan atau kumpulan prosedur berbasis model untuk memproses data dan pertimbangan untuk membantu manajemen dalam pembuatan keputusannya.Menurut Keen (1980), Sistem Pendukung Keputusan adalah sistem berbasis komputer yang dibangun lewat sebuah proses adaptif dari pembelajaran, pola-pola penggunaan dan evolusi sistem. Menurut Man dan Watson, Sistem Pendukung Keputusan merupakan suatu sistem yang interaktif, yang membantu pengambil keputusan melalui penggunaan data dan model-model keputusan untuk memecahkan masalah yang sifatnya semi terstruktur maupun yang tidak terstruk tur. 


\section{B. Raskin (Beras Miskin)}

Raskin (beras miskin) merupakan subsidi pangan sebagai upaya pemerintah untuk mening katkan ketahanan pangan dan memberikan perlindungan pada keluarga miskin melalui pendistri busian beras yang diharapkan mampu menjangkau keluarga miskin.Tujuan pelaksanaan raskin ini yaitu untuk membantu keluarga miskin agar memperoleh subsidi beras miskin sebagai bagian dari upaya program pemerintah untuk perlindungan sosial masyarakat. Melalui sebuah kajian ilmiah, penamaan RASKIN menjadi nama program diharapkan akan menjadi lebih tepat sasaran dan mencapai tujuan RASKIN.(TNP2K.2014).

\section{Pengertian Topsis}

Technique Order Performance by Similarity to Ideal Solution(TOPSIS) adalah salah satu metode pengambilan keputusan multikriteria yang pertama kali diperkenalkan oleh Yoon dan Hwang pada tahun 1981. Metode TOPSIS didasarkan pada konsep, dimana alternative terpilih yang baik tidak hanya memiliki jarak terpendek dari solusi ideal positif, namun juga memiliki jarang terpanjang dari solusi ideal negative.Solusi ideal positif memaksimalkan kriteria keuntungan dan meminimalkan kriteria biaya. Solusi idel negative memaksimalkan kriteria biaya dan meminimalkan kriteria keuntungan ( Fan dan Cheng 2009 : 4).Technique Order Performance by Similarity to Ideal Solution (TOPSIS) didasarkan pada konsep dimana alternative terpilih yang terbaik tidak hanya memiliki jarak terpendek dari solusi ideal positif, namun juga memiliki jarak terpanjang dari solusi ideal negative [4].

\section{Langkah-Lanagkah Metode Topsis}

1. Pada langkah ini, proses dilakukan dimulai dengan menghitung bobot setiap kriteria (1-5)

Tabel 1 Keterangan Nilai Bobot

\begin{tabular}{|l|l|}
\hline 1 & Sangat Rendah \\
\hline 2 & Rendah \\
\hline 3 & Cukup \\
\hline 4 & Tinggi \\
\hline 5 & Sangat Tinggi \\
\hline
\end{tabular}

2. Buat sebuah matriks xij yang terdiri dari $\mathrm{m}$ alternatif dan $\mathrm{n}$ kriteria

Tabel 2 Perbandingan alternative dan kriteria

\begin{tabular}{|l|l|l|l|l|l|}
\hline \multicolumn{1}{|c|}{$\begin{array}{c}\text { Alternative/ } \\
\text { kriteria }\end{array}$} & K1 & K2 & K2 & K3 & K4 \\
\hline A1 & & & & & \\
\hline A2 & & & & & \\
\hline A3 & & & & & \\
\hline A4 & & & & & \\
\hline
\end{tabular}

3. Hitung Normalized Decission Matrix (Matriks Keputusan ternormalisasi).

$$
r_{i j}=\frac{x_{i j}}{\sqrt{\sum_{i=1}^{m} x_{i j}^{2}}}
$$

Gambar 1 Rumus Menghitung Matriks Ternormalisasi

4. Hitung Weight Normalized Decission Matrix ( Matriks Keputusan ternormalisasi dan terbobot).

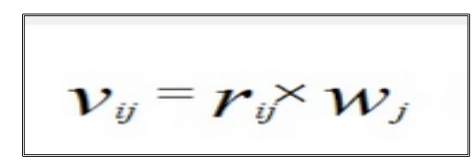

Gambar 2 Rumus Menghitung Matriks Ternormalisasi Terbobot 
5. Mencari nilai maksimal dan minimal dari normalisasi terbobot.

6. Mencari D+ dan D- untuk setiap alternatif.

$D x+=\sqrt{(A x C 1-Y 1+)^{2}+(A x C 1-Y 2+)^{2}+\cdots+(A x C n-Y n+)^{2}}$

Gambar 3 Rumus Menghitung Solusi Ideal

Positif

$D x+=\sqrt{(A x C 1-Y 1-)^{2}+(A x C 1-Y 2-)^{2}+\cdots+\left(A x C n-Y_{n-}\right)^{2}}$

Gambar 4 Rumus Menghitung Solusi Ideal

Negatif

7. Mencari Hasil ( merangking alternative)

$$
\mathrm{V} x=\frac{D x-}{(D x-)+(D x+)}
$$

Gambar 4 Rumus Menghitung Preferensi

\section{METODOLOGI PENELITIAN}

Penulis menggunakan beberapa metode penelitian untukmengarahkan penelitian (perancangan) ini agar tujuan peneliti yang telah ditentukan dapat tercapai. Beberapa metode penelitian yang digunakan penulis sebagai berikut :

\section{A. Metode Penelitian}

Dalam penelitian ini digunakan metode action research.Pengertian dari metode action researchadalah kegiatan dan atau tindakan perbaikan sesuatu yang perencanaan, pelaksanaan, dan evaluasinya digarap secara sistematik sehingga validitas dan reliabilitasnya mencapai tingkatan riset. Action research juga merupakan proses yang mencakup siklus aksi, yang mendasarkan pada refleksi, umpan balik (feedback), bukti (evidence), dan evaluasi atas aksi sebelumnya dan situasi sekarang.Penelitian tindakan bertujuan untuk memperoleh pengetahuan untuk situasi atau sasaran khusus dari pada pengetahuan yang secara ilmiah tergeneralisasi.untuk lebih jelasnya alur penelitian action research dijelaskan pada gambar dibawah ini:

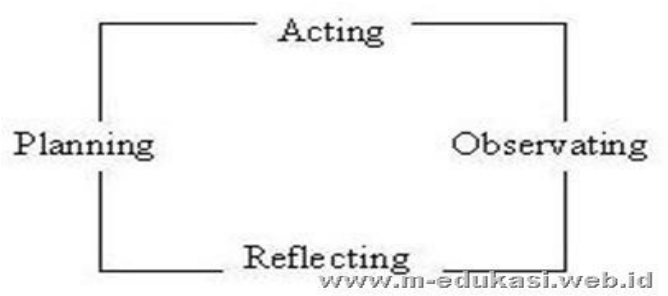

Gambar 5. Action Research Model Kurt Lewin

Gambar 5 di atas merupakan beberapa tahapan dalam penelitian action research yang dilakukan. Penjelasan setiap proses adalah sebagai berikut:

\section{Menyusun perencanaan (planning)}

Pada tahap ini kegiatan yang harus dilakukan adalah mempersiapkan fasilitas dari sarana pendukung yang diperlukan dalam penelitian, mempersiapkan instrument untuk merekam dan menganalisis data mengenai proses dan hasil tindakan.

2. Melaksanakan tindakan (acting).

Pada tahap ini peneliti melakukan tindakan yang telah dirumuskan, dalam situasi yang actual, yang meliputi kegiatan awal, inti dan penutup.

3. Melaksanakan pengamatan (observing)

Tahap penelitian disini adalah tahap pengumpulan data. Tahap ini dimaksudkan untuk mengumpulkan data pendukung yang dibutuhkan dalam proses penelitian yaitu dengan cara observasi dan wawancara.

4. Melakukan refleksi (reflecting)

Pada tahap ini adalah mencatat hasil observasi, mengevaluasi hasil observasi, menganalisis hasil pembelajaran, mencatat kekurangan kekurangan 
untuk dijadikan bahan penyusunan rancangan sistem pendukung keputusan agar tujuan tercapai.

\section{B. Metode Pengumpulan Data}

Metode pengumpulan data berdasarkan jenis datanya, data yang dikumpulkan dalam penelitian ini adalah sebagai berikut :

\section{Data Primer}

Data primer adalah data yang diambil langsung dari obyek penelitian atau merupakan data yang berasal dari sumber asli atau pertama. Teknik pengumpulan data primer dilakukanmelalui teknik observasi dengan cara mengumpulkan informasi informasi langsung ke lokasi penelitian untuk mengamati bagaimana penentuan dan pembagian RASKIN yang dilakukan oleh pihak pemerintah daerah di Desa Mekar Sari dengan cara pengamatan dan pencatatan dengan peninjauan langsung dan wawancara dengan melakukan wawancara terstruktur dengan menyediakan daftar pertanyaan untuk mewawancarai perangkat desa mengenai bagaimana pembagian RASKIN yang diterapkan selama ini. Data yang dihasilkan yaitu informasi berupa opini dari pihak tersebut.

\section{Data Sekunder}

Data sekunder adalah data yang tidak didapatkan secara langsung dari objek penelitian, melainkan data yang berasal dari sumber yang telah dikumpulkan oleh pihak lain. Teknik pengumpulan data sekunder dilakukan dengan cara studi dokumentasi dan studi literatur.

\section{HASIL DAN PEMBAHASAN}

Analisa acuan dalam membangun sistem pendukung keputusan ini berdasarkan penilaian secara umum dilakukan pada proses penerimaan raskin (beras miskin). Dimana dalam penilaian ini setiap kepala keluarga akan dinilai berdasarkan kriteria dan alternative, di bawah ini adalah table kriteria dan alternatif yang akan di uji dengan metode Technique Order Performance by Similarity to Ideal Solution (TOPSIS). Diperlukan kriteria-kriteria dan bobot untuk melakukan perhitungannya sehingga akan di dapat alternative terbaik. Dalam metode penelitian ini ada bobot dan kriteria yang dibutuhkan untuk menentukan siapa yang akan terseleksi sebagai calon penerima raskin. Adapun kriterianya adalah :

K1 = Kondisi Rumah, K2 = Tempat Buang Air, K3 = Bahan Bakar masak, K4 = Sumber Penerangan, K5 = Makan Perhari, K6 = Pekerjaa, K7 = Kemampuan Berobat.

Proses pencarian hasil penelitian tampak pada tahapan berikut.

1. Menentukan nilai bobot kepentingan dari setiap kriteria.

Tabel 3. Bobot Kriteria

\begin{tabular}{|c|c|c|c|c|c|c|c|c|}
\hline 1 & & $\begin{array}{r}\text { Kondisi } \\
\text { Rumah } \\
\end{array}$ & $\begin{array}{l}\text { Teupat } \\
\text { Buang. } .1 \text { ir }\end{array}$ & $\begin{array}{l}\text { Balanan Bakar } \\
\text { Masak }\end{array}$ & $\begin{array}{c}\text { Sumber } \\
\text { Penerangana }\end{array}$ & $\begin{array}{l}\text { Jakan } \\
\text { Perhari }\end{array}$ & Pekerjaan & $\begin{array}{c}\text { Kemamplan } \\
\text { Berobat } \\
\end{array}$ \\
\hline & Bobot & 4 & 4 & 3 & 5 & 4 & 5 & 4 \\
\hline
\end{tabular}

2. Selanjutnya membentuka matriks perbandingan alternative dan kriteria.

Tabel 4 Matriks Perbandingan

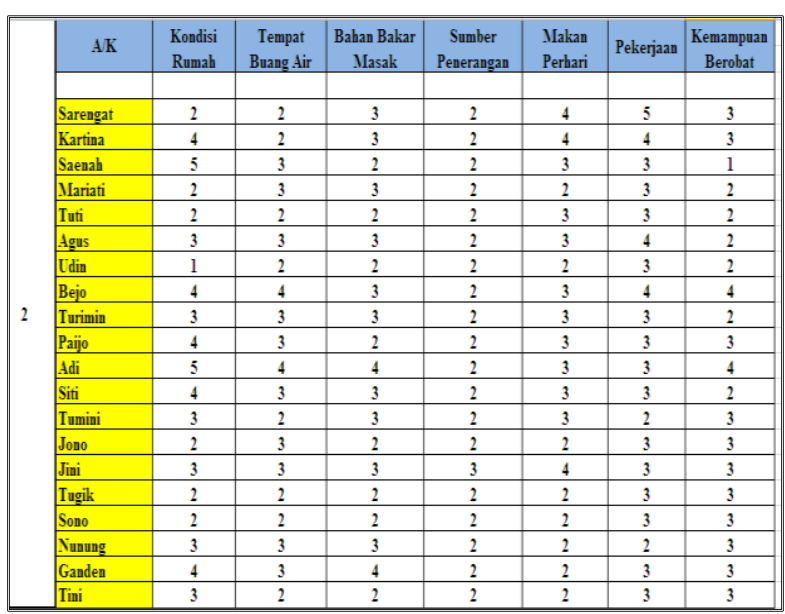


3. Membentuk matriks keputusan ternormalisasi

Dalam menentukan matrik keputusan ternormalisasi, nilai tiap kriteria (xij) untuk keseluruhan alternatif dijumlahkan kemudian nilai masing-masing kriteria tersebut dibagi dengan hasil jumlah kriterianya.

Tabel 5 Matriks Ternormalisasi

\begin{tabular}{|c|c|c|c|c|c|c|c|c|}
\hline \multirow{21}{*}{3} & $A / K$ & $\begin{array}{l}\text { Kondisi } \\
\text { Rumah }\end{array}$ & $\begin{array}{c}\text { Tempat } \\
\text { Buang Air }\end{array}$ & $\begin{array}{c}\text { Bahan Bakar } \\
\text { Masak }\end{array}$ & \begin{tabular}{c|} 
Sumber \\
Penerangan
\end{tabular} & $\begin{array}{l}\text { Makan } \\
\text { Perhari }\end{array}$ & Pekerjaan & $\begin{array}{c}\text { Kemampuan } \\
\text { Berobat }\end{array}$ \\
\hline & rengat & 0.1383429 & 0.16116459 & \begin{tabular}{|l|}
0.241746889 \\
\end{tabular} & 0.216930458 & 0.31524416 & 0.347524 & 0.24019223 \\
\hline & Kartina & 0.2766858 & 0.16116459 & 0.241746889 & 0.216930458 & 0.31524416 & \begin{tabular}{|l|l|}
0.2780192 \\
\end{tabular} & 0.24019223 \\
\hline & saenah & 8458572 & 0.24174689 & \begin{tabular}{|l|}
0.161164593 \\
\end{tabular} & 0.216930458 & 0.23643312 & \begin{tabular}{|l|l|}
0.2085144 \\
\end{tabular} & \\
\hline & mariati & & 0.24174689 & \begin{tabular}{|l|}
0.241746889 \\
\end{tabular} & 0.216 & 0.15762208 & 0.2085144 & 0.1601 \\
\hline & Tuti & 0.1383429 & 0.16116459 & \begin{tabular}{|l|}
0.161164593 \\
\end{tabular} & 0.2169 & 0.23643312 & 0.2085144 & 0.16012815 \\
\hline & Agus & 0.2075143 & 0.24174689 & \begin{tabular}{|l|}
0.241746889 \\
\end{tabular} & 0.216 & 0.23643312 & & \\
\hline & Udin & 0.0691714 & 0.16116459 & \begin{tabular}{|l|}
0.161164593 \\
\end{tabular} & 0.2169 & 0.15762208 & 0.2085144 & 0.16012815 \\
\hline & Bejo & 0.2766858 & 0.32232919 & \begin{tabular}{|l|}
0.241746889 \\
\end{tabular} & 0.216930458 & 0.23643312 & 0.2780192 & 0.32025631 \\
\hline & Turimin & 0.2075143 & 0.2417 & \begin{tabular}{|l|l|}
0.241746889 \\
\end{tabular} & 0.216 & 0.236 & 0.20 & 0.16 \\
\hline & Paijo & 0.2766858 & 0.241 & \begin{tabular}{|l|}
0.161164593 \\
\end{tabular} & 0.216 & 0.23643312 & \begin{tabular}{|l|l|}
0.2085144 \\
\end{tabular} & 0.24019223 \\
\hline & Adi & 0.3458572 & 0.3223 & 0.322329186 & 0.2 & 0.236 & 0.208 & \\
\hline & Siti & 2766858 & 0.24174689 & 0.2417 & 0.2169 & 0.23643312 & 44 & 0.16012815 \\
\hline & Tumini & 2075143 & 0.161 & 0.241 & 0.216 & 0.23643312 & 096 & 0.24019223 \\
\hline & Jono & 0.1383429 & & & & 0.15762208 & & 0.24019223 \\
\hline & Jini & 0.2075143 & 0.24174689 & \begin{tabular}{|l|}
0.241746889 \\
\end{tabular} & 0.325395687 & 0.31524416 & 0.2085144 & 0.24019223 \\
\hline & Tugik & & & & & 0.15762208 & 1144 & 0.2 \\
\hline & Sono & 0.138 & 0.16 & \begin{tabular}{|ll}
6 \\
\end{tabular} & 0.2 & 0.15762208 & 55144 & 0.2401 \\
\hline & Nunun & 0.2075143 & 0.24174689 & \begin{tabular}{|l|}
0.241746889 \\
\end{tabular} & 0.2169 & 0.15762208 & 0.1390096 & 0.24019223 \\
\hline & Gand & & & & & & & \\
\hline & Tini & 0.2075143 & 0.16116459 & \begin{tabular}{|l|}
0.161164593 \\
\end{tabular} & 0.216930458 & 0.15762208 & \begin{tabular}{|l|l|}
0.2085144 \\
\end{tabular} & 0.24019223 \\
\hline
\end{tabular}

4. Selanjutnya membentuk matriks keputusan ternormalisasi dan terbobot

Tabel 6 Matriks Ternormalisasi terbobot

\begin{tabular}{|c|c|c|c|c|c|c|c|c|}
\hline \multirow{21}{*}{4} & $\mathrm{AK}$ & $\begin{array}{l}\text { Kondisi } \\
\text { Rumah }\end{array}$ & \begin{tabular}{c|} 
Tempat \\
Buang Air
\end{tabular} & \begin{tabular}{|c|} 
Bahan Bakar \\
Masak
\end{tabular} & $\begin{array}{c}\text { Sumber } \\
\text { Penerangan }\end{array}$ & $\begin{array}{l}\text { Makan } \\
\text { Perhari }\end{array}$ & Pekerjaan & \begin{tabular}{|c|} 
Kemampuan \\
Berobat
\end{tabular} \\
\hline & \begin{tabular}{|l} 
Sarengat \\
\end{tabular} & 0,5533716 & $\begin{array}{l}0,64465837 \\
\end{array}$ & \begin{tabular}{|l|}
0.725240668 \\
\end{tabular} & 1,084652289 & 126097665 & 1.7376201 & 0.96076892 \\
\hline & Kartina & 1.1067431 & \begin{tabular}{|l|}
0.64465837 \\
\end{tabular} & \begin{tabular}{|l|}
0.725240668 \\
\end{tabular} & 1.084652289 & 1.26097665 & 1.3900961 & 0.96076892 \\
\hline & saenah & 1.3834289 & \begin{tabular}{|l|}
0.96698756 \\
\end{tabular} & \begin{tabular}{|l|}
0.483493778 \\
\end{tabular} & 1.084652289 & 0.94573249 & 1.0425721 & 0.32025631 \\
\hline & mariati & 0.5533716 & 0.96698756 & 0.725240668 & 1.084652289 & 0.63048832 & 1.0425721 & 0.64051262 \\
\hline & Tuti & 0.5533716 & \begin{tabular}{|l|}
0.64465837 \\
\end{tabular} & \begin{tabular}{|l|}
0.483493778 \\
\end{tabular} & 1.084652289 & 0.94573249 & 1.0425721 & 0.64051262 \\
\hline & Agus & 0.8300574 & 0.96698756 & 0.725240668 & 1.084652289 & 0.94573249 & 1.3900961 & 0.64051262 \\
\hline & Udin & 0.2766858 & \begin{tabular}{|l|}
0.64465837 \\
\end{tabular} & \begin{tabular}{|l|}
0.483493778 \\
\end{tabular} & 1.084652289 & 0.63048832 & 1.0425721 & 0.64051262 \\
\hline & Bejo & 1.1067431 & 1.28931674 & 0.725240668 & 1.084652289 & 0.94573249 & 1.3900961 & 1.28102523 \\
\hline & Turimin & 0.8300574 & \begin{tabular}{|l|}
0.64465837 \\
\end{tabular} & \begin{tabular}{|l|}
0.725240668 \\
\end{tabular} & 1.084652289 & 0.94573249 & 0.695048 & \begin{tabular}{|l|l|}
0.96076892 \\
\end{tabular} \\
\hline & Paijo & 1.1067431 & 0.96698756 & 0.483493778 & 1.084652289 & 0.94573249 & 1.0425721 & 0.96076892 \\
\hline & Adi & 1.3834289 & 1.28931674 & 0.966987557 & 1.084652289 & 0.94573249 & 1.0425721 & 1.28102523 \\
\hline & Siti & 1.1067431 & 0.96698756 & 0.725240668 & 1.084652289 & 0.94573249 & 1.0425721 & \begin{tabular}{|l|l|}
1.64051262 \\
\end{tabular} \\
\hline & Tumini & 0.8300574 & \begin{tabular}{|l|}
0.64465837 \\
\end{tabular} & \begin{tabular}{|l|l|}
0.725240668 \\
\end{tabular} & 1.084652289 & 0.94573249 & 0.695048 & 0.96076892 \\
\hline & Jono & 0.5533716 & $\begin{array}{l}0.96698756 \\
\end{array}$ & \begin{tabular}{|l|}
0.483493778 \\
\end{tabular} & 1.084652289 & 0.63048832 & 1.0425721 & 0.96076892 \\
\hline & Jini & 0.8300574 & $\begin{array}{l}0.96698756 \\
\end{array}$ & \begin{tabular}{|l|}
0.725240668 \\
\end{tabular} & 1.626978434 & 1.26097665 & 1.0425721 & 0.96076892 \\
\hline & Tugik & 0.5533716 & $\begin{array}{l}0.64465837 \\
\end{array}$ & \begin{tabular}{|l|}
0.483493778 \\
\end{tabular} & 1.084652289 & 0.63048832 & 1.0425721 & 0.96076892 \\
\hline & \begin{tabular}{|l|} 
Sono \\
\end{tabular} & 0.5533716 & 0.64465837 & \begin{tabular}{|l|}
0.483493778 \\
\end{tabular} & 1.084652289 & 0.63048832 & 1.0425721 & 0.96076892 \\
\hline & Sunung & 0.8300574 & 0.96698756 & 0.725240668 & 1.084652289 & 0.63048832 & 0.695048 & 0.96076892 \\
\hline & Ganden & 1.1067431 & 0.96698756 & 0.966987557 & 1.084652289 & 0.63048832 & 1.0425721 & 0.96076892 \\
\hline & Tini & 0.8300574 & $\begin{array}{l}0.64465837 \\
\end{array}$ & \begin{tabular}{|l|}
0.483493778 \\
\end{tabular} & 1.084652289 & 0.63048832 & 1.0425721 & 0.96076892 \\
\hline
\end{tabular}

5. Menentukan nilai maksimal dan minimal dari normalisasi terbobot.

Tabel 7 Nilai Min dan Max Matriks Ternormalisasi

Terbobot

\begin{tabular}{|c|c|c|c|c|c|c|c|c|}
\hline \multirow{3}{*}{5} & & \begin{tabular}{l|} 
Kondisi \\
Rumah
\end{tabular} & \begin{tabular}{|c|} 
Tempat \\
Buang Air \\
\end{tabular} & \begin{tabular}{|c|} 
Bahan Bakar \\
Ilasak \\
\end{tabular} & \begin{tabular}{|c|} 
Sumber \\
Penerangan
\end{tabular} & $\begin{array}{l}\text { Nlakan } \\
\text { Perhari } \\
\end{array}$ & Pekerjaan & $\begin{array}{c}\text { Kemampuan } \\
\text { Berobat }\end{array}$ \\
\hline & IAIX & 1.38342893 & 1.289316742 & 0.966987567 & 1.626078434 & 1.26097665 & 1.7376201 & $1 \quad 1.28102523$ \\
\hline & III & \begin{tabular}{|l|l|}
0.27668579 \\
\end{tabular} & 0.644688371 & 0.483493778 & 1.084652289 & 0.63048832 & 0.695048 & 80.320256308 \\
\hline
\end{tabular}

Hasil dari proses pencarian nilai min dan max berdasarkan matriks ternormalisasi terbobot di atas akan menjadi acaun/dasar dalam mendapatkan solusi ideal positif dan solusi ideal negatif. Pada solusi ideal positif nilai yang digunakan hanyalah nilai max. Sedangkan pada pencarian solusi ideal negatif angka yang digunakan adalah nilai min.

6. Selanjutnya menentukan nilai Solusi ideal positif (D+) dan solusi ideal negatif (D-) untuk setiap alternatif.

Tabel 8. Tabel D+ dan D-

\begin{tabular}{|c|c|c|c|c|c|c|}
\hline \multirow{20}{*}{6} & \multirow{20}{*}{$\mathrm{D}+$} & Sarengat & 1.248880674 & \multirow{20}{*}{ D- } & Sarengat & 1.42468419 \\
\hline & & Kartina & 1.033458124 & & Kartina & 1.42769062 \\
\hline & & saenah & 1.461960183 & & saenah & 1.24455949 \\
\hline & & mariati & 1.56086971 & & mariati & 0.67987479 \\
\hline & & Tuti & 1.620243991 & & Tuti & 0.63187891 \\
\hline & & Agus & 1.180289644 & & Agus & 1.07405425 \\
\hline & & Udin & 1.859895805 & & Udin & 0.47258549 \\
\hline & & Bejo & 0.805770475 & & Bejo & 1.63357546 \\
\hline & & Turimin & 1.537290871 & & Turimin & 0.93503847 \\
\hline & & Paijo & 1.180410852 & & Paijo & 1.19302119 \\
\hline & & Adi & 0.936262953 & & Adi & 1.7370837 \\
\hline & & Siti & 1.235207437 & & Siti & 1.08353533 \\
\hline & & Tumini & 1.537290871 & & Tumini & 0.93503847 \\
\hline & & Jono & 1.517875693 & & Jono & 0.84349303 \\
\hline & & Jini & 1.026749068 & & Jini & 1.30046926 \\
\hline & & Tugik & 1.617292469 & & Tugik & 0.77947699 \\
\hline & & Sono & 1.617292469 & & Sono & 0.77947699 \\
\hline & & Nunung & 1.532876889 & & Nunung & 0.93745089 \\
\hline & & Ganden & 1.20736912 & & Ganden & 1.24807328 \\
\hline & & Tini & 1.494275681 & & Tini & 0.91501336 \\
\hline
\end{tabular}

7. Rangking Alternatif

Pada proses ini akan dilakukan penentuan nilai preferensi sebagai dasar menentukan hasil perengkingan berdasarkan nilai tertinggi 
Tabel 9 hasil perangkingan

\begin{tabular}{||l|c|c|l|c|c||}
\hline \multicolumn{3}{|c}{ Rangking } & \multicolumn{2}{c|}{ Rangking } \\
\cline { 1 - 1 } Sarengat & 0.53287811 & 5 & Adi & 0.649778695 & 2 \\
\hline Kartina & 0.58009116 & 3 & Siti & 0.467294322 & 9 \\
\hline saenah & 0.45983759 & 10 & Tumini & 0.378201422 & 12 \\
\hline mariati & 0.30341469 & 18 & Jono & 0.357205133 & 15 \\
\hline Tuti & 0.28057035 & 19 & Jini & 0.558808447 & 4 \\
\hline Agus & 0.47643762 & 8 & Tugik & 0.325219845 & 16 \\
\hline Udin & 0.20261063 & 20 & Sono & 0.325219845 & 17 \\
\hline Bejo & 0.66967765 & 1 & Nunung & 0.379484414 & 13 \\
\hline Turimin & 0.37820142 & 11 & Ganden & 0.508288559 & 6 \\
\hline Paijo & 0.50265656 & 7 & Tini & 0.379785632 & 14 \\
\hline
\end{tabular}

\section{KESIMPULAN}

Dari hasil pengujian sistem yang telah dilakukan, maka dapat diambil beberapa kesimpulan daiantaranya sebagai berikut:

1. Sistem Pendukung keputusan untuk menentukan penerima Raskin di Desa Mekar Sari ini dapat membantu pihak pemerintah daerah dalam menentukan penerima Raskin dengan mengambil nilai hasil akhir penerima yang tertinggi.

2. Berdasarkan pengujian sistem yang dilakukan, perbedaan penggunaan sistem pendukung keputusan penerima Raskin dapat menyaring $75 \%$ penerima atau sebanyak $15 \mathrm{KK}$ dari 20 sampel KK yang seharusnya tidak layak menerima bantuan.

3. Sistem ini hanya menjadi alat bantu bagi pengambil keputusan, keputusan akhir tetap berada di tangan pengambil keputusan.

\section{SARAN}

Saran yang dapat diberikan penulis untuk pengembangan selanjutnya yaitu dapat dikembangkan dengan metode lainnya sebagai perbandingan keakuratan dengan studi kasus yang sama ataupun berbeda. Sehingga dapat dilihat perbandingan keputusan yang dihasilkan dari beberapa teori.

\section{DAFTAR PUSTAKA}

[1]. Galih,Setiawan dkk.(2011). TOPSIS(Technique For Others Reference by Similarity to Ideal Solution.Yogyakarta, Makalah (UniversitasIslam Negeri Sunan Kalijaga).

[2]. Hasan, M. Iqbal, Ir. M.M.. (2002). Pokokpokok Materi Teori Pengambilan Keputusan, Ghalia Indonesia, Jakarta.Hwang, Ching Lai, and Yoon K. (1981).

[3]. Kadarsah S, 1998, Sistem Pendukung Keputusan, Jakarta.

[4]. Kusumadewi, Sri dkk. 2006, Fuzzy MultiAttribute Decision Making (Fuzzy MADM). Yogyakarta: Graha Ilmu.

[5]. Situmorang, H. (2016). Sistem Pendukung Keputusan Pemilihan Calon Peserta Olimpiade Sains Tingkat Kabupaten Langkat pada Madrasah Aliyah Negeri (MAN) 2 TanjungPura dengan Menggunakan Metode TOPSIS. Jurnal

TIMES, 4(2), 24-30.

[6]. Turban E, Jaye Aronson, Peng-LiangTing.( 2005). Decision System andIntekegent System. Yogyakarta, Andi. 